\title{
Higher Pulmonary Vein Index From Preoperative Computed Angiography \& Good Surgical Resection Ensures A Smooth Post-Operative Recovery Sans Low Cardiac Output Syndrome in a TOF Child-Special Emphasis On Indices Of Evaluation, Monocusp Preparation.
}

Vishal Bhende $^{1}$, DR.TANISHQ S. SHARMA ${ }^{1}$, DR.DEEPAK V. KUMAR MEHTA ${ }^{1}$, Krishnan Subramaniam ${ }^{1}$, DR. AMIT KUMAR ${ }^{1}$, Badra Trivedi ${ }^{1}$, Jigar Thacker ${ }^{1}$, DR. B. VIRAL PATEL ${ }^{1}$, DR. GURPREET PANESAR ${ }^{1}$, DR.KUNAL SONI ${ }^{1}$, DR.KARTIK DHAMI $^{1}$, DR.HARDIL P. MAJMUDAR ${ }^{1}$, DR. NIRJA PATEL ${ }^{1}$, and R.PATHAN SOHILKHAN ${ }^{1}$

${ }^{1}$ Pramukhswami Medical College

January 24, 2022

\begin{abstract}
Tetralogy of Fallot (TOF) is a common cyanotic congenital heart disease. Its surgical correction requires ventricular septal defect (VSD) closure and right ventricular outflow tract obstruction (RVOTO) relief, with transannular patch enlargement (TAPE) of the pulmonary valve. The first successful repair of TOF was reported in 1954 and consisted of closure of the VSD through a large right ventriculotomy, and RVOTO relief with TAPE of the pulmonary valve. To predict the intra-operative requirements and post-operative course of patients with this condition, various evaluation indices are available that can provide a good indication of patient prognosis. In this case report, we describe a novel pulmonary vein index (PVI) indicator that offers prognostic indications for pediatric cardiac patients who have undergone surgical correction of TOF.
\end{abstract}

Higher Pulmonary Vein Index From Preoperative Computed Angiography \& Good Surgical Resection Ensures A Smooth Post-Operative Recovery Sans Low Cardiac Output Syndrome in a TOF Child-Special Emphasis On Indices Of Evaluation, Monocusp Preparation.

Author Information - 1) Vishal V. Bhende Primary Author, Consultant,Pediatric Cardiac Surgery, Bhanubhai and Madhuben Patel Cardiac Centre,Shree Krishna Hospital,Gokal Nagar,Karamsad,Anand,Gujarat 388 325,India. E mail:drvishalbhende@gmail.com Mobile : + 919845383405 2) Tanishq S. Sharma, Corresponding Author, Pediatric Cardiac Surgery, Bhanubhai and Madhuben Patel Cardiac Centre, Shree Krishna Hospital,Karamsad,Anand,Gujarat - 388 325,India. E mail:sharma.tanishqtask@gmail.com Mobile : + 91 7990243174 3) Deepakkumar V. Mehta Professor \& Head,Department of Radiodiagnosis \& Imaging, Pramukhswami Medical College \& Shree Krishna Hospital, Bhaikaka University,Karamsad,Anand,Gujarat - 388 325,India. E mail:deepakvm@charutarhealth.org Mobile : + 919879167676

4) Krishnan Ganapathy Subramaniam

Consultant,Cardiac Surgeon,Mgm Healthcare, Aminjikarai, Chennai

E mail : ganapathysubramaniamk@gmail.com 
Mobile : 09600050895 5) Amit Kumar Consultant,Pediatric Cardiac Intensivist, Bhanubhai and Madhuben Patel Cardiac Centre,Shree Krishna Hospital,Karamsad,Anand,Gujarat - 388 325,India. $\quad$ E mail:amitpaed2006@yahoo.com Mobile : + 918238010476

6) Bhadra Y. Trivedi Consultant,Pediatric Interventional Cardiologist,Bhanubhai and Madhuben Patel Cardiac Centre,Shree Krishna Hospital,Karamsad,Anand,Gujarat - 388 325,India. E mail:Bhadra81@gmail.com Mobile : + 919987718447 7) Jigar P. Thacker

Assistant Professor,Department Of Pediatrics, Pramukhswami Medical College, Bhaikaka University, Karamsad

E mail: thackerjigar@yahoo.co.in

Mobile : 9426621883

8) Viral B. Patel Professor,Department of Radiodiagnosis \& Imaging, Pramukhswami Medical College \& Shree Krishna Hospital, Bhaikaka University, Karamsad,Anand,Gujarat - 388 325,India. E mail:viralvp@charutarhealth.org Mobile : + 919825060977 9)Gurpreet Panesar Consultant,Cardiac Anaesthesiology, Bhanubhai and Madhuben Patel Cardiac Centre, Shree Krishna Hospital,Karamsad,Anand,Gujarat - 388 325,India. E mail:Panesar_preeti@yahoo.co.in Mobile : + 9198253 58661 10)Kunal Soni Consultant,Cardiac Anaesthesiology, Bhanubhai and Madhuben Patel Cardiac Centre, Shree Krishna Hospital,Karamsad,Anand,Gujarat - 388 325,India. E mail:drkunalsoni@gmail.com Mobile : + 919099921950 11)Kartik B. Dhami Consultant,Cardiac Anaesthesiology, Bhanubhai and Madhuben Patel Cardiac Centre, Shree Krishna Hospital,Karamsad,Anand,Gujarat - 388 325,India. E mail:kartikbdhami@yahoo.com Mobile : + 919179473521 12)Hardil P. Majmudar Cardiac Surgery, Bhanubhai and Madhuben Patel Cardiac Centre,Shree Krishna Hospital,Karamsad,Anand,Gujarat - 388 325,India. E mail: hardil.majmudar@gmail.com Mobile : + 919265903713

13)Nirja Patel Fellow,Cardiac Anaesthesiology,Bhanubhai and Madhuben Patel Cardiac Centre, Shree Krishna Hospital,Karamsad,Anand,Gujarat - 388 325,India. E mail:nirjapatel27@gmail.com Mobile : + 91 7575801142

14) Sohilkhan Pathan Clinical Research Co-ordinator, Bhanubhai and Madhuben Patel Cardiac Centre, Shree Krishna Hospital,Karamsad,Anand,Gujarat - 388 325,India. E mail:sohilrp@charutarhealth.org Mobile : + 918460063464

\begin{abstract}
Tetralogy of Fallot (TOF) is a common cyanotic congenital heart disease. Its surgical correction requires ventricular septal defect (VSD) closure and right ventricular outflow tract obstruction (RVOTO) relief, with transannular patch enlargement (TAPE) of the pulmonary valve. The first successful repair of TOF was reported in 1954 and consisted of closure of the VSD through a large right ventriculotomy, and RVOTO relief with TAPE of the pulmonary valve. To predict the intra-operative requirements and post-operative course of patients with this condition, various evaluation indices are available that can provide a good indication of patient prognosis. In this case report, we describe a novel pulmonary vein index (PVI) indicator that offers prognostic indications for pediatric cardiac patients who have undergone surgical correction of TOF.
\end{abstract}

\title{
KEYWORDS -
}

Tetralogy of Fallot, Pulmonary vein index, McGoon ratio, early outcomes, congenital heart disease.

\section{Introduction}

Tetralogy of Fallot (TOF) is a cyanotic congenital heart disease seen in pediatric patients. Successful surgical correction of TOF was first performed in 1954 with the closure of the ventricular septal defect (VSD) through a large right ventriculotomy and relief of RVOTO by transannular patch enlargement (TAPE) $[1,2]$. 
Since then, treatments for the correction of TOF have enjoyed tremendous success [3,4]. The peri-operative mortality rate has reduced to $1.5 \%$ and there are good long-term outcomes due to the evolution of cardiopulmonary bypass techniques and peri-operative management. Although TOF can be lethal if untreated or incorrectly treated; it can have an excellent prognosis with timely surgical intervention.

The ideal TOF repair removes RVOTO sufficiently to prevent the progression of right ventricular hypertrophy. However, there are remarkable clinical differences between TOF patients, which may lead to overconfidence when formulating treatment decisions and predicting prognoses. TOF patients can experience prolonged postoperative recovery even when surgery is successful $[5,6]$.

Reduced pulmonary blood flow (Qp) is the main cause of hemodynamic changes in TOF. Presently, preoperative evaluations of TOF children are performed using the McGoon ratio and the Nakata index but these have limitations. Both of these systems measure branch pulmonary arteries (PAs), which can yield fallacious results as pulmonary arteries are not typically cylindrical.Differences may be present as normal anatomic variations,or as a result of factors that may increase the stiffness of the vessels,and thus affect the ability of the PAs to alter their shape in response to changing conditions. In addition, poststenotic dilatation of branch PAs, the presence of major aortopulmonary collateral arteries (MAPCAs), and malformations may lead to misjudgments of Qp and further influence the mis-estimation of the patient's condition and the determination of poor treatment decisions. Thus, understanding of the pulmonary artery anatomy is essential for all decisions -making in pediatric cardiac surgery.

In this study, we aim to demonstrate that the sizes of individual pulmonary veins (PVs) are a more accurate and sensitive indicator of $\mathrm{Qp}$ than PA size, especially in TOF patients $[7,8]$. The pulmonary vein index (PVI) is a new indicator based on the morphology of pulmonary veins. As Qp and the severity of TOF are inversely proportional, PVI may provide more precise predictions.

We review the case of a TOF patient who underwent complete repair in our institution and compare the prognostic abilities of PVI and the McGoon ratio and Nakata index in their predictions of early postoperative TOF outcomes.

\section{Case Presentation}

Our study was approved by the Institutional Ethics Committee (IEC-2) of the HM Patel Centre for Medical Care and Education, Anand,Gujarat vide Approval No.IEC/BU/2021/Cr.54/296 dated 27.11.2021. Written informed consent to use the patient's data in this study was obtained from a parent or guardian prior to surgery.

The patient was male,aged 1 year,9 months and 23 days;weighed $8.5 \mathrm{kgs}$. Weight at birth was $2.5 \mathrm{kgs}$. The patient presented with TOF and confluent branch PAs, with a history of cyanotic spells.At surgery,the patient's pre-operative oxygen saturation was $75 \%$. The patient had never undergone a surgical procedure prior to this. The Mc Goon ratio was 1.97 ,Nakata Index was $539.22 \mathrm{~mm} 2 / \mathrm{m} 2$ and PVI was $368.12 \mathrm{~mm} 2 / \mathrm{m} 2$. The operative data comprised a cardiopulmonary bypass(CPB)time of $152 \mathrm{~min}$. The surgical strategy included combination of four procedures - Ventricular septal defect (VSD) closure, Right ventricular outflow tract (RVOT) resection, Trans-annular patch enlargement(TAPE), Atrial Septal Defect closure.A summary of the patient information is presented in Table2.

A cardiac computed tomography dynamic study revealed confluent branch PAs in our patient. The measurements for these were: right pulmonary artery: proximal $9 \mathrm{~mm}$, distal $8.3 \mathrm{~mm}$; left pulmonary artery: proximal $11 \mathrm{~mm}$, distal $12 \mathrm{~mm}$; main pulmonary artery: proximal (supra-valvular region) $7.7 \mathrm{~mm}$, mid 9 $\mathrm{mm}$, distal $12.2 \mathrm{~mm}$.

Table - 1 Indices Used in the Evaluation of TOF Patients

\begin{tabular}{lll}
\hline Sr. No. & Indices & Description \\
\hline Preoperative & Preoperative & Preoperative
\end{tabular}




\begin{tabular}{|c|c|c|}
\hline Sr. No. & Indices & Description \\
\hline 1 & Pulmonary Vein Index (PVI) & $\begin{array}{l}\text { Designed to determine the } \\
\text { predictive value of PVI for early } \\
\text { outcomes among surgical } \\
\text { treatment of TOF patients. PVI } \\
=\mathrm{LPV}-\mathrm{A}+\mathrm{RPV}-\mathrm{A} / \mathrm{Body} \\
\text { Surface Area (BSA) }\left(\mathrm{m}^{2}\right) \\
/ \mathrm{mm}^{2} / \mathrm{m}^{2} \text { The area of the Pas is } \\
\text { measured at the proximal point of } \\
\text { the first branch. The area of the } \\
\text { PVs (LPV-A, RPV-A) is } \\
\text { measured } 3 \mathrm{~mm} \text {. beyond the } \\
\text { pulmonary venous ostium. }\end{array}$ \\
\hline 2 & McGoon Ratio & $\begin{array}{l}\text { This is the sum of diameters of } \\
\text { immediately prebranching left and } \\
\text { right pulmonary arteries to } \\
\text { descending aorta just above the } \\
\text { level of the diaphragm. - Normal } \\
\text { value more than } 2 \text { to } 2.5 \text {. }\end{array}$ \\
\hline
\end{tabular}

The Nakata index is a

cross-sectional area of the left and right pulmonary artery in $\mathrm{mm}^{2}$

divided by total body surface area (BSA). Cross-sectional area is measured by $(\pi \times 2 /$ diameter $\times$ magnification coefficient expressed for BSA). The cross-sectional area is calculated by using the formula, $\pi \times \mathrm{r}^{2} \times$ magnification coefficient where, $r=$ radius or $\frac{1}{2}$ of the measured PA diameters. Normal Nakata value is $330+/-30$

Nakata Index

Total Neo-pulmonary Artery Index [TNPAI] $\mathrm{mm}^{2} / \mathrm{BSA}$.

Suggested as an indicator of postoperative RV/LV pressure ratio. TNPAI is calculated by determining the cross-sectional area of the PAs (as described by Nakata et.al.) and the MAPCAs and dividing the result by body surface area $\left(\mathrm{mm}^{2} / \mathrm{m}^{2}\right)$. TNPAI $=$ APC index + Nakata index / BSA Where, APC index is the sum of CSA of all usable APC's N.B. - APC = aortopulmonary collaterals; CSA $=$ Cross-sectional area 


\begin{tabular}{|c|c|c|}
\hline 5 & Pulmonary Annulus Index (PAI) & $\begin{array}{l}\text { Actual Pulmonary Annulus } \\
\text { Diameter }\left(\mathrm{PAD}_{\mathrm{A}}\right) / \mathrm{PAI}= \\
\text { Expected Pulmonary Annulus } \\
\text { Diameter }\left(\mathrm{PAD}_{\mathrm{E}}\right) \mathrm{PAD}_{\mathrm{E}}=\mathrm{PAD}_{\mathrm{A}} \\
+\mathrm{AAD} / 2 \text { where, } \mathrm{AAD}=\text { Aortic } \\
\text { Annulus Diameter }\end{array}$ \\
\hline 6 & $\begin{array}{l}\text { Z Score (Established by } \\
\text { Rowlatt, Rinoldi and Lev) }\end{array}$ & $\begin{array}{l}\text { OBSERVED VALUE - } \\
\text { EXPECTED } \\
\text { VALUE/STANDARD } \\
\text { DEVIATION (S.D.) OF THE } \\
\text { EXPECTED VALUE }\end{array}$ \\
\hline 7 & $\begin{array}{l}\text { Transannular patch enlargement } \\
\text { (TAPE) of the pulmonary valve }\end{array}$ & $\begin{array}{l}\text { PULMONARY VALVE } \\
\text { ANNULUS (PVA) SIZE / } \\
\text { AORTIC VALVE ANNULUS } \\
\text { (AVA) SIZE TAPE = OR PVA / } \\
\text { AVA GREAT ARTERY } \\
\text { ANNULUS SIZE RATIO [GA } \\
\text { RATIO] }\end{array}$ \\
\hline Intraoperative - PRV: LV & Intraoperative - PRV: LV & Intraoperative - PRV: LV \\
\hline Ratio $\{$ Kirklin's Index $\}<$ & Ratio $\{$ Kirklin's Index $\}<$ & Ratio $\{$ Kirklin's Index $\}<$ \\
\hline $\begin{array}{l}0.7=\text { optimal }>0.8= \\
\text { TAPE }\end{array}$ & $\begin{array}{l}0.7=\text { optimal }>0.8= \\
\text { TAPE }\end{array}$ & $\begin{array}{l}0.7=\text { optimal }>0.8= \\
\text { TAPE }\end{array}$ \\
\hline Postoperative & Postoperative & Postoperative \\
\hline 8 & $\begin{array}{l}\text { Tricuspid Annular Plane Systolic } \\
\text { Excursion (TAPSE) }\end{array}$ & $\begin{array}{l}\text { TAPSE is another } \\
\text { two-dimensional measure with } \\
\text { which one can assess systolic right } \\
\text { ventricular function. TAPSE in } \\
\text { pediatric patients. Normal }>12 \\
\text { mm. Mild RV dysfunction } 10-12 \\
\text { mm. Moderate RV dysfunction } \\
8-10 \mathrm{~mm} \text {. Severe RV dysfunction } \\
<7 \mathrm{~mm} \text {. }\end{array}$ \\
\hline 9 & Fractional Area Change (FAC) & $\begin{array}{l}\text { The fractional area change is a } \\
\text { two-dimensional measure of right } \\
\text { ventricular global systolic } \\
\text { function. RV FAC ( } \% \text { ) Reference } \\
\text { range } 32 \%-60 \% \text { Mild abnormal } \\
25 \%-31 \% \text { Moderate abnormal } \\
18 \%-24 \% \text { Severe abnormal }<17 \%\end{array}$ \\
\hline 10 & $\begin{array}{l}\text { Pulmonary Regurgitation (PR) in } \\
\text { Postoperative TOF for } \\
\text { Determining Right Ventricular } \\
\text { Contractile Dysfunction }\end{array}$ & $\begin{array}{l}\text { PR is classified as: Mild (No } \\
\text { retrograde diastolic flow in the } \\
\text { pulmonary trunk with a } \\
\text { detectable regurgitant jet in the } \\
\text { RV outflow tract) Moderate } \\
\text { (retrograde diastolic flow in the } \\
\text { main pulmonary artery) Severe } \\
\text { (additional retrograde diastolic } \\
\text { flow in branch PAs). }\end{array}$ \\
\hline
\end{tabular}




\begin{tabular}{|c|c|c|}
\hline 5 & Pulmonary Annulus Index (PAI) & $\begin{array}{l}\text { Actual Pulmonary Annulus } \\
\text { Diameter }\left(\mathrm{PAD}_{\mathrm{A}}\right) / \mathrm{PAI}= \\
\text { Expected Pulmonary Annulus } \\
\text { Diameter }\left(\mathrm{PAD}_{\mathrm{E}}\right) \mathrm{PAD}_{\mathrm{E}}=\mathrm{PAD}_{\mathrm{A}} \\
+\mathrm{AAD} / 2 \text { where, } \mathrm{AAD}=\text { Aortic } \\
\text { Annulus Diameter }\end{array}$ \\
\hline 11 & $\begin{array}{l}\text { Isovolumic Myocardial } \\
\text { Acceleration (IVA) }\end{array}$ & $\begin{array}{l}\text { Experimental and a clinical study } \\
\text { as a new tissue Doppler-based } \\
\text { index of systolic RV function } \\
\text { post-TOF repair. - IVA } \\
\text { demonstrates reduced contractile } \\
\text { function in relation to the degree } \\
\text { of PR and may be an early, } \\
\text { sensitive index for selecting } \\
\text { patients for valve replacement. }\end{array}$ \\
\hline 12 & $\begin{array}{l}\text { Pulmonary Regurgitation (PR) } \\
\text { used to calculate pulmonary } \\
\text { artery diastolic pressure (using } \\
\text { the modified bernoulli equation) } \\
\text { and mean pulmonary artery } \\
\text { pressure }\end{array}$ & $\begin{array}{l}\text { PADP = RVEDP }+ \text { I" Ppv } \\
\text { Where, PADP = Pulmonary } \\
\text { artery diastolic pressure RVEDP } \\
\text { = Right ventricular diastolic } \\
\text { pressure I" Ppv = Equals the } \\
\text { pressure gradient between the } \\
\text { pulmonary artery and right } \\
\text { ventricular outflow tract. } \\
\text { Calculate the end-diastolic } \\
\text { gradient between the pulmonary } \\
\text { artery and right ventricular } \\
\text { outflow tract from the velocity of } \\
\text { the pulmonary regurgitation jet. } \\
\text { Add, assumed RVDP = RAP, } \\
\text { then the equation can be applied - } \\
\text { PADP = RVEDP }+\hat{\mathrm{I}} \text { " Ppv } \\
\text { PA } A_{\text {mean }}=(\mathrm{PA} \text { Systolic }+2 \\
\left.\text { PA }_{\text {diastolic }}\right) / 3\end{array}$ \\
\hline
\end{tabular}

TABLE 2 - BENEFITS OF EARLY COMPLETE REPAIR OF TOF

Growth activity of body and organs

Reducing Hypoxemia

Limited right ventricular muscle excision

Preservation of left ventricular function

Reduced incidence of late dysrhythmias

TABLE 2 - PATIENT INFORMATION

\begin{tabular}{ll}
\hline BASIC CHARACTERISTICS & BASIC CHARACTERISTICS \\
Age, years & 1 year, 9 months, 23 days \\
Weight, kgs. & $8.5 \mathrm{kgs}$. \\
Sex & Male \\
Birth Weight & $2.5 \mathrm{kgs}$.
\end{tabular}




\begin{tabular}{ll} 
Pre-operative oxygen saturation & $75 \%$ \\
Cyanotic Spells & + \\
Previous Surgical Procedure & Nil \\
McGoon ratio & 1.97 \\
Nakata Index & $539.22 \mathrm{~mm}^{2} / \mathrm{m}^{2}$ \\
Pulmonary Vein Index & $368.12 \mathrm{~mm}^{2} / \mathrm{m}^{2}$ \\
OPERATIVE DATA & OPERATIVE DATA \\
CPB Time & $196 \mathrm{Min}$. \\
ACC Time & $152 \mathrm{Min}$. \\
SURGICAL STRATEGY & SURGICAL STRATEGY \\
With TAP & + \\
ASSOCIATED PROCEDURES & ASSOCIATED PROCEDURES \\
ASD closure & + \\
\hline
\end{tabular}

N.B. : CPB - Cardio-Pulmonary Bypass, ACC - Aortic Cross-Clamp, TAP-Trans-annular patch, ASD Atrial septal defect, RVP/LVP : Post-operative right and left ventricle pressure ratio, PVI-Pulmonary vein Index.

13 ) Prediction of Post-operative Residual Shunts

(A) RV (or PA) systolic pressure (PASP) can be estimated from the velocity of the tricuspid regurgitation (TR) jet, if present, by the following equation:

RVSP $($ or PASP) $=4(\mathrm{~V}) 2+$ RA pressure where $\mathrm{V}$ is the TR jet velocity.

For example,

If the TR velocity is $2.5 \mathrm{~m} / \mathrm{sec}$

Then, RVSP or PASP $=4(2.5) 2+$ RA pressure

$=25 \mathrm{~mm} \mathrm{Hg}+\mathrm{RA}$ pressure

Assuming RA pressure is $10 \mathrm{~mm} \mathrm{Hg}$ and if no PS

Then, RVSP or PASP $=35 \mathrm{~mm} \mathrm{Hg}$.

(B) RV (or PA) systolic pressure can also be estimated from the velocity of the VSD jet by the following equation:

RVSP $($ or PASP) $=$ Systemic SP $($ or arm SP) $-4(\mathrm{~V}) 2$

where V is the VSD jet.

For example, if the VSD jet flow velocity is $3 \mathrm{~m} / \mathrm{sec}$, the instantaneous pressure drop between the LV and $\mathrm{RV}$ is $4 \times(3) 2=36 \mathrm{~mm}$. Hg.

RVSP $($ or PASP) $=36 \mathrm{~mm}$. Hg.

If LVSP is assumed to be $90 \mathrm{~mm}$. Hg., the RVSP is (LVSP-RVSP) $=(90-36)=54 \mathrm{~mm}$. Hg.

In the absence of PS, the PASP will be about $54 \mathrm{~mm} \mathrm{Hg}$.

(C)LVSP can be estimated from the velocity of flow through the aortic valve (V) by the following equation: $\operatorname{LVSP}=4(\mathrm{~V}) 2+$ Systemic SP $($ or arm SP)

where $\mathrm{V}$ is the aortic flow velocity.

N.B. Arm pressure is usually 5 to $10 \mathrm{~mm}$. $\mathrm{Hg}$ is higher than the LV systolic pressure. 
Significant pulmonary regurgitation (PR) can occur after the repair of TOF. Although the PR has been well tolerated for a decade or two, moderate to severe PR may eventually develop when there is significant RV dilatation and dysfunction. This requires the surgical insertion of a homograft pulmonary valve. RV function is best assessed by MRI 2-D echocardiography.

Surgical Technique -

The operation was performed on our patient with full-flow cardiopulmonary bypass and moderate hypothermia using repeated Del Nido crystalloid cardioplegia under general anesthesia.

Glutaraldehyde treated pericardial patch closure of the ventricular septal defect was performed with the continuous running of 5/0 polypropylene sutures through the right atrial (RA) approach. We then resected the right ventricular outflow tract (RVOT) via trans-atrial and trans-outflow approaches. We reconstructed the PTFE monocusp valve 0.1 membrane of the RVOT. We then employed TAPE augmentation.

\section{Monocusp Preparation}

We first measured the circumference of the RVOT from points A to C using black silk marking. A Hegar dilator two sizes larger than required for the patient's body weight was employed. We used the marked silk threads for width (point A, B, C) and the Hegar dilator to shape the membrane. Finally, we sutured the vertex of the membrane to the native area of the pulmonary valve and both the ends to the width ends of the RVOT using 6-0 polypropylene sutures.

Results

A molecular assay for the qualitative detection of SARS-CoV-2 was performed; the results of which were negative. The patient then underwent a detailed cardiological evaluation, including an electrocardiogram, a 2D echocardiogram, and a cardiac CT dynamic study.

The patient's PVI was $368.12 \mathrm{~mm} 2 / \mathrm{m} 2$, which resulted in a smooth, uneventful postoperative course, with no symptoms of low cardiac output syndrome.

In this study,we evaluated the predictive value of PVI for the determination of early post-operative outcomes among patients with TOF.A reduced PVI is a significant risk factor for both early mortality and prolonged post-operative recovery.

Cardiac CT Dynamic study is a valuable tool that can provide detailed information on the morphology of extra-cardiac vessels,viz., the coronary vessels,PAs,aorta,and pulmonary and systemic veins.

A secondary objective of this case report was to assess the performance of polytetrafluoroethylene monocusp valves (PTFE-MVs). PTFE-MVs do not calcify in the membrane. Instead, a well-vascularized layer of nonobstructive fibrocollagenous tissue is incorporated into the PTFE with focal areas of endothelialization. The MV integrates with the RVOT patch to variable degrees. Reconstruction of the RVOT with a PTFE-MV has proven a simple, reproducible technique with excellent early postoperative function and minimal PR. Early clinical benefits are seen in patients reconstructed with a monocusp valve compared with those who undergo TAP repairs. Hence, the PVI with PTFE-MV reconstruction of the RVOT is a valuable preoperative predictor of the early prognosis of TOF patients.

\section{TABLE 3 - POST-OPERATIVE DATA}

\begin{tabular}{ll}
\hline RVOT Peak gradient (mm.Hg.) & $12 \mathrm{~mm} . \mathrm{Hg}$. \\
RVP /LVP & 0.4 \\
Ventilator Hours & 122 Hours \\
& $(5$ days, 2 hours, 8 minutes) \\
Length of ICU stay & 11 days \\
Hospital Stay & 14 days \\
Major Complications & Nil
\end{tabular}


TABLE 4 - Arterial Blood Gases done in the patient on POD 1,3,5,7 with trends in lactate and potassium $\left(\mathrm{K}^{+}\right)$levels. POD -Post-operative day.

\begin{tabular}{|c|c|c|c|c|c|}
\hline & $1^{\text {st }}$ POD & $3^{\text {rd }}$ POD & $5^{\text {th }}$ POD & $7^{\text {th }}$ POD & \\
\hline $\mathrm{pH}$ & 7.50 & 7.43 & 7.44 & 7.46 & $\mathrm{mmHg}$ \\
\hline pCO2 & 35 & 36 & 42 & 35 & $\mathrm{mmHg}$ \\
\hline $\mathrm{pO} 2$ & 152 & 129 & 127 & 174 & $\mathrm{mmol} / \mathrm{L}$ \\
\hline $\mathrm{Na}+$ & 148 & 139 & 135 & 133 & $\mathrm{mmol} / \mathrm{L}$ \\
\hline $\mathrm{K}+$ & 3.1 & 3.3 & 3.5 & 4.2 & $\mathrm{mmol} / \mathrm{L}$ \\
\hline $\mathrm{Ca}++$ & 1.00 & 1.10 & 1.13 & 1.13 & $\mathrm{mmol} / \mathrm{L}$ \\
\hline Glu & 198 & 148 & 97 & 95 & $\mathrm{mg} / \mathrm{dL}$ \\
\hline Lac & 1.8 & 1.1 & 0.8 & 1.0 & $\mathrm{mmol} / \mathrm{L}$ \\
\hline Hct & 41 & 42 & 37 & 38 & $\%$ \\
\hline $\mathrm{Ca}++(7.4)$ & 1.04 & 1.11 & 1.15 & 1.16 & $\mathrm{mmol} / \mathrm{L}$ \\
\hline HCO3- & 27.3 & 23.9 & 28.5 & 24.9 & $\mathrm{mmol} / \mathrm{L}$ \\
\hline HCO3 std & 28.3 & 24.9 & 28.0 & 26.0 & $\mathrm{mmol} / \mathrm{L}$ \\
\hline TCO2 & 28.4 & 25.0 & 29.8 & 26.0 & $\mathrm{mmol} / \mathrm{L}$ \\
\hline BE ecf & 4.1 & -0.4 & 4.3 & 1.1 & $\mathrm{mmol} / \mathrm{L}$ \\
\hline BE (B) & 4.2 & -0.1 & 3.9 & 1.3 & $\mathrm{mmol} / \mathrm{L}$ \\
\hline S02c & 99 & 99 & 99 & 100 & $\%$ \\
\hline THbc & 12.7 & 13.0 & 11.5 & 11.8 & $\mathrm{~g} / \mathrm{dL}$ \\
\hline A-aDO2 & 54 & 40 & 34 & -18 & $\mathrm{mmHg}$ \\
\hline pAO2 & 206 & 169 & 161 & 156 & $\mathrm{mmHg}$ \\
\hline $\mathrm{paO} 2 / \mathrm{pAO} 2$ & 0.74 & 0.76 & 0.79 & 1.12 & \\
\hline
\end{tabular}

TABLE 5 - MINIMUM ACCEPTABLE PULMONARY VALVE RING DIAMETER (EMPLOYED BY KIRKLIN IN 1975,1976)

\begin{tabular}{llll}
\hline WEIGHT(KGS.) & MIN.RING SIZE DIAMETER (MM.) & AREA(MM $\left.{ }^{2}\right)$ & $\frac{1}{2}$ SIZE \\
& 4 & 13 & \\
& 5 & 20 & \\
3 & 6 & 28 & 4 \\
4 & 7 & 39 & 5 \\
5 & 7.5 & 45 & 5.5 \\
6 & 8 & 50 & 6 \\
7 & 9 & 64 & 6.5 \\
8 & 9.5 & 72 & 7 \\
9 & 10 & 79 & 7.5 \\
10 & 11 & 85 & 8.5 \\
12 & 12 & 113 & 9 \\
14 & 13 & 133 & 9.5 \\
16 & 13.5 & 144 & 10 \\
18 & 14 & 154 & 11 \\
20 & 15 & 177 & 11 \\
25 & 17 & 227 & 12 \\
30 & 18.5 & 270 & 13 \\
35 & 20 & 314 & 14 \\
40 & 20 & 314 & 14 \\
\hline
\end{tabular}

TABLE 6 - MEAN NORMAL VALVE DIAMETERS 


\begin{tabular}{lllll}
\hline BSA $\left(\mathrm{m}^{2}\right)$ & MITRAL & TRICUSPID & AORTIC & PULMONARY \\
0.25 & 11.2 & 13.4 & 7.2 & 8 \\
0.30 & 12.6 & 14.9 & 8.1 & 9 \\
0.35 & 13.6 & 16.2 & 8.9 & 10 \\
0.40 & 14.4 & 17.3 & 9.5 & 10 \\
0.45 & 15.2 & 18.2 & 10.1 & 11 \\
0.50 & 15.8 & 19.2 & 10.7 & 11 \\
0.60 & 16.9 & 20.7 & 11.5 & 12 \\
0.70 & 17.9 & 21.9 & 12.3 & 13 \\
0.80 & 18.8 & 23.0 & 13.0 & 14 \\
0.90 & 19.7 & 24.0 & 13.4 & 14 \\
1.00 & 20.2 & 24.9 & 14.0 & 15 \\
1.20 & 21.4 & 26.2 & 14.8 & 16 \\
1.40 & 22.3 & 27.7 & 15.5 & 17 \\
1.60 & 23.1 & 28.9 & 16.1 & 17 \\
1.80 & 23.8 & 29.1 & 16.5 & 18 \\
2.00 & 24.2 & 30.0 & 17.2 & 18 \\
\hline
\end{tabular}

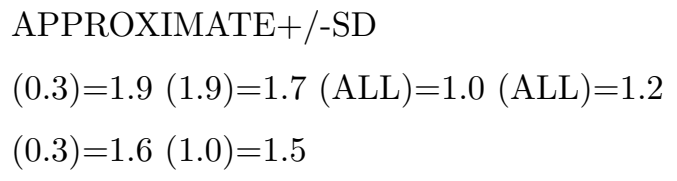

TABLE 7 - SUGGESTED CRITERIA FOR SURGICAL PULMONARY VALVE REPLACEMENT

GEVAT (2006) based on RV regurgitant fraction RV regurgitation fraction $>=25 \%$ PLUS Two or more of the following crit $\mathrm{RV}$ end - diastolic volume index $>=160 \mathrm{ml} / \mathrm{m}^{2}$ (Normal values, $<108 \mathrm{ml} / \mathrm{m}^{2}$

RV end-systolic volume index $>=70 \mathrm{ml} / \mathrm{m}^{2}$ (Normal values, $<47 \mathrm{ml} / \mathrm{m}^{2}$

$\mathrm{LV}$ end-diastolic volume index $>=65 \mathrm{ml} / \mathrm{m}^{2}$

RV ejection fraction $<=45 \%$

RV outflow tract aneurysm

Clinical Criteria Exercise intolerance Syncope Presence of heart failure sustained ventricular tachycardia or* $Q R S$ duration death

VIDEO - 1 VIDEO COMMENTARY OF POST-OPERATIVE ICR

Link: https://youtu.be/y7c6qrCNmHQ

\section{Discussion}

There have been numerous attempts to establish useful prognostic indicators for congenital heart disease. Some indices that have shown good prognostic value include the McGoon ratio, Nakata index, pulmonary arterial index, and TNPAI. More recently, the PVI has been indicated as a predictor for early outcomes during the surgical treatment of patients with TOF. In this study, we determine the predictive value of PVI. Yuan et al, in their study, indicated that a reduced PVI is a significant risk factor for early death and prolonged postoperative recovery. They estimated the cut-off point of PVI at $300.3 \mathrm{~mm} 2 / \mathrm{m} 2$. In our case, PVI is $368.12 \mathrm{~mm} 2 / \mathrm{m} 2$, which resulted in a smoother and uneventful postoperative recovery.

Pulmonary blood flow has a major effect on the prognosis of patients with CHDs, and PA parameters, such as the McGoon ratio and Nakata index, are the most commonly used parameters for the evaluation of 
pulmonary blood flow and as prognostic indicators for the successful surgical repair of TOF. However, it has been shown that PVI provides a more accurate indicator of pulmonary blood flow than that of the PAs.

Another objective of this case report was to assess the performance of PTFE-MVs. Construction of the PTFE-MV is an inexpensive and straightforward way to create a competent RVOT in a variety of RVOTO anomalies [16,17]. Moreover, reports show that PTFE-MVs appeared equal or superior to biologic monocusp valves, providing perioperative RVOT competence and improved right ventricular functional characteristics, reduced ICU stay, and decreased operative morbidity and mortality in patients with TOF [17].

Although the literature has been inconclusive regarding the perioperative function and clinical benefit of PTFE-MV for RVOT reconstruction, PTFE-MV has proven to be a simple and reproducible technique demonstrating excellent early postoperative function with minimal pulmonary insufficiency [18]. All types of monocusps have shown, particularly in the immediate postoperative period, to significantly reduce or prevent pulmonary insufficiency. The elimination of pulmonary insufficiency is associated with faster recovery of RV function, a lower central venous pressure, and less postoperative chest tube drainage [19]. A review of 196 patients demonstrated only mild to moderate insufficiency in $58 \%$ of patients at 10 years, and no significant RVOT stenosis. In our study, we show that PVI with PTFE-MV reconstruction for RVOT is a valuable preoperative predictor for early prognosis in TOF.

The patient in our case report underwent a detailed cardiological evaluation with electrocardiogram, 2D echocardiography, and cardiac CT dynamic study. Cardiac CT is a noninvasive technique that offers several approaches to establish the hemodynamic severity of coronary artery obstructions, demonstrates a good correlation with directly measured coronary flow and fractional flow reserve [20], and provides incremental diagnostic value over coronary CT angiography alone for the identification of hemodynamically significant coronary artery disease [21].

\section{Conclusions}

In this case report, we determine how the PVI will impact the postoperative outcome of surgically treated patients with TOF, and whether we can correlate the indices and postoperative recovery. The other aspect of the study is the performance of PTFE-MV. The PTFE-MV does not calcify in the membrane but rather a well-vascularized layer of nonobstructive fibrocollagenous tissue is incorporated within the PTFE with focal areas of endothelialization. Thus, the PTFE-MV integrates with the RVOT patch to a variable degree.

Reconstruction of the RVOT with a PTFE MO valve has proven to be a simple and reproducible technique demonstrating excellent early postoperative function with minimal PR. Moreover, there is a degree of early clinical benefit in patients reconstructed with a PTFE-MV when compared with TAP repairs. Hence, PVI with PTFE-MV for RVOT reconstruction is a valuable preoperative predictor for early prognosis of patients with TOF. In addition, cardiac CT dynamic study is a valuable tool recommended as it is a noninvasive technique that can pin-point the morphology of extra-cardiac vessels.

\section{ACKNOWLEDGEMENTS -}

We are thankful to -

Mr. Naresh Jayantibhai Fumakiya, Echo-Cardiographer, Bhanubhai and Madhuben Patel Cardiac Centre, Shree Krishna Hospital, Karamsad.

Mr. Khushal N. Vankar, Office Assistant, Department of Diagnostic Services, Shree Krishna Hospital, Bhaikaka University, Karamsad.Email : khushalnv@charutarhealth.org

\section{References}

1. Gott VL: Total correction of tetralogy of Fallot. Ann Thorac Surg. 1990, 49:328-332. 10.1016/00034975(90)90167-5 
2. Lillehei CW, Cohen M, Warden HE, et al.: Direct vision intracardiac surgical correction of the tetralogy of Fallot, pentalogy of Fallot and pulmonary atresia defects. Reports of the first 10 cases. Ann Surg. 1955, 142:418-442. 10.1097\%2F00000658-195509000-00010

3. Sarris GE, Comas JV, Tobata Z, et al.: Results of reparative surgery for tetralogy of Fallot:data from the European Association for cardio-thoracic surgery congenital database. Eur J Cardiothorac Surg. 2012, 766:74. 10.1093/ejcts/ezs478

4. Kirklin JW, Ellis FJ, McGoon DC, et al.: Surgical treatment for the tetralogy of Fallot by open intracardiac repair. J Thorac Surg. 1959, 22:51. 10.1016/S0096-5588(20)30094-5

5. Chowdhury UK, Jha A, Ray R, et al.: Histopathology of the right ventricular outflow tract and the relation to hemodynamics in patients with repaired tetralogy of Fallot. J Thorac Cardiovasc Surg. 2019, 1173:83. 10.1016/j.jtcvs.2019.03.118

6. Karamlou T, McCrindle BW, Williams WG, et al.: Surgery insight: late complications following repair of tetralogy of Fallot and related surgical strategies for management. Nat Clin Pract Cardiovasc Med. 2006, 3:611-22. 10.1038/ncpcardio0682

7. Jia Q, Cen J, Zhuang J, et al.: Significant survival advantage of high pulmonary vein index and the presence of native pulmonary artery in pulmonary atresia with ventricular septal defect and major aortopulmonary collateral arteries: results from preoperative computed tomography angiography. Eur J Cardiothorac Surg. 52:225-32. 10.1093/ejcts/ezx064

8. Kawahira Y, Kishimoto H, Kawata H, et al.: Diameters of the pulmonary arteries and veins as an indicator of bilateral and unilateral pulmonary blood flow in patients with congenital heart disease. J Card Surg. 1997, 253:60. 10.1111/j.1540-8191.1997.tb00136.x

9. Yuan H, Qian T, Huang T, et al.: Pulmonary vein index is associated with early prognosis of surgical treatment for tetralogy of Fallot [Internet]. Frontiers in pediatrics. Frontiers Media S.A.; July. 2021, 9:705553-2021. 10.3389\%2Ffped.2021.705553

10. Garekar S., Dhobe P.,Chokhandre M, et al.: Estimation of Z-Scores of Cardiac Structures in Healthy. Indian Pediatric Population, Journal of the Indian Academy of Echocardiography \& Cardiovascular Imaging : Volume 2: Issue 3 : September-December. 2018, 10.4103/jiae.jiae_48_18

11. R. Krishna Kumar: Accuracy of a New Echocardiographic index to predict need for Trans-annular patch in Tetralogy of Fallot. Pediatric Cardiology40:161-167. 10.1007/s00246-018-1973-x

12. Choi KH: A Novel Predictive value for the Transannular patch enlargement in repair of Tetralogy of Fallot. Ann Thorac Surg. 2016, 101:703-7. 10.1016/j.athoracsur.2015.10.050

13. Stewart RD, Backer CL, Young L, et al.: Tetralogy of Fallot: results of a pulmonary valve-sparing strategy. Ann Thorac Surg. 2005, 80:1431-9. 10.1016/j.athoracsur.2005.04.016

14. Awori MN, Leong W, Artrip JH, et al.: Tetralogy of Fallot repair: optimal z-score use for transannular patch insertion. Eur J Cardiothorac Surg. 2013, 43:483-6.

15. Frigiola A: Pulmonary Regurgitation is an important determinant of Right Ventricular Contractile Dysfunction in Patients with Surgically Repaired Tetralogy of Fallot. Circulation. 2004110, 153:157. 10.1161/01.CIR.0000138397.60956.c2

16. Turrentine MW, McCarthy RP, Vijay P, et al.: Polytetrafluoroethylene monocusp valve technique for right ventricular outflow tract reconstruction. Ann Thorac Surg. 2002, 74:2202-5. 10.1016/S00034975(02)03844-4

17. Turrentine MW, McCarthy RP, Vijay $\mathrm{P}$, et al.: PTFE monocusp valve reconstruction of the right ventricular outflow tract. Ann Thorac Surg. 2002, 73:871-80. 10.1016/S0003-4975(01)03441-5

18. Turrentine MW, Rodefeld MD, Brown, JW: Polytetrafluoroethylene monocusp valve reconstruction of the right ventricular outflow tract. Oper Tech Thorac Cardiovasc Surg. 2008, 13:250-9. 10.1053/j.optechstcvs.2008.11.002

19. Brown JW, Ruzmetov M, Vijay P, et al.: Right ventricular outflow tract reconstruction with a polytetrafluoroethylene monocusp valve: a twelve-year experience. J Thorac Cardiovasc Surg. 2007, 133:1336-43. 10.1016/j.jtcvs.2006.12.045

20. Nieman K, Balla S: Dynamic CT myocardial perfusion imaging. J Cardiovasc Comput Tomogr. 2020, 14:303-6. 10.1016/j.jcct.2019.09.003 
21. Nous FM, Geisler T, Kruk MB, et al.: Dynamic myocardial perfusion ct for the detection of hemodynamically significant coronary artery disease. JACC Cardiovasc Imaging. (In. 2021101016202107021, 10.1016/j.jcmg.2021.07.021
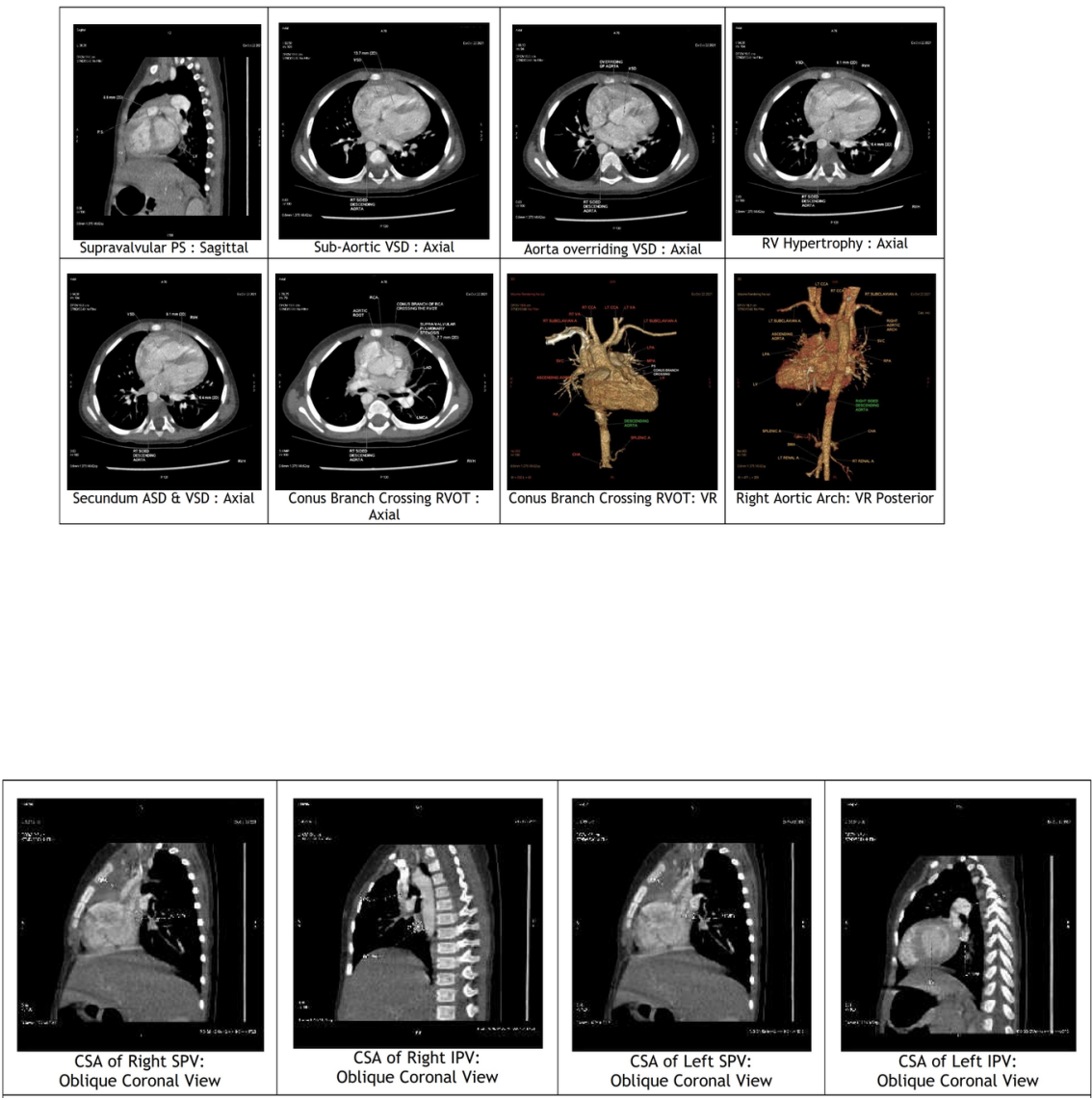


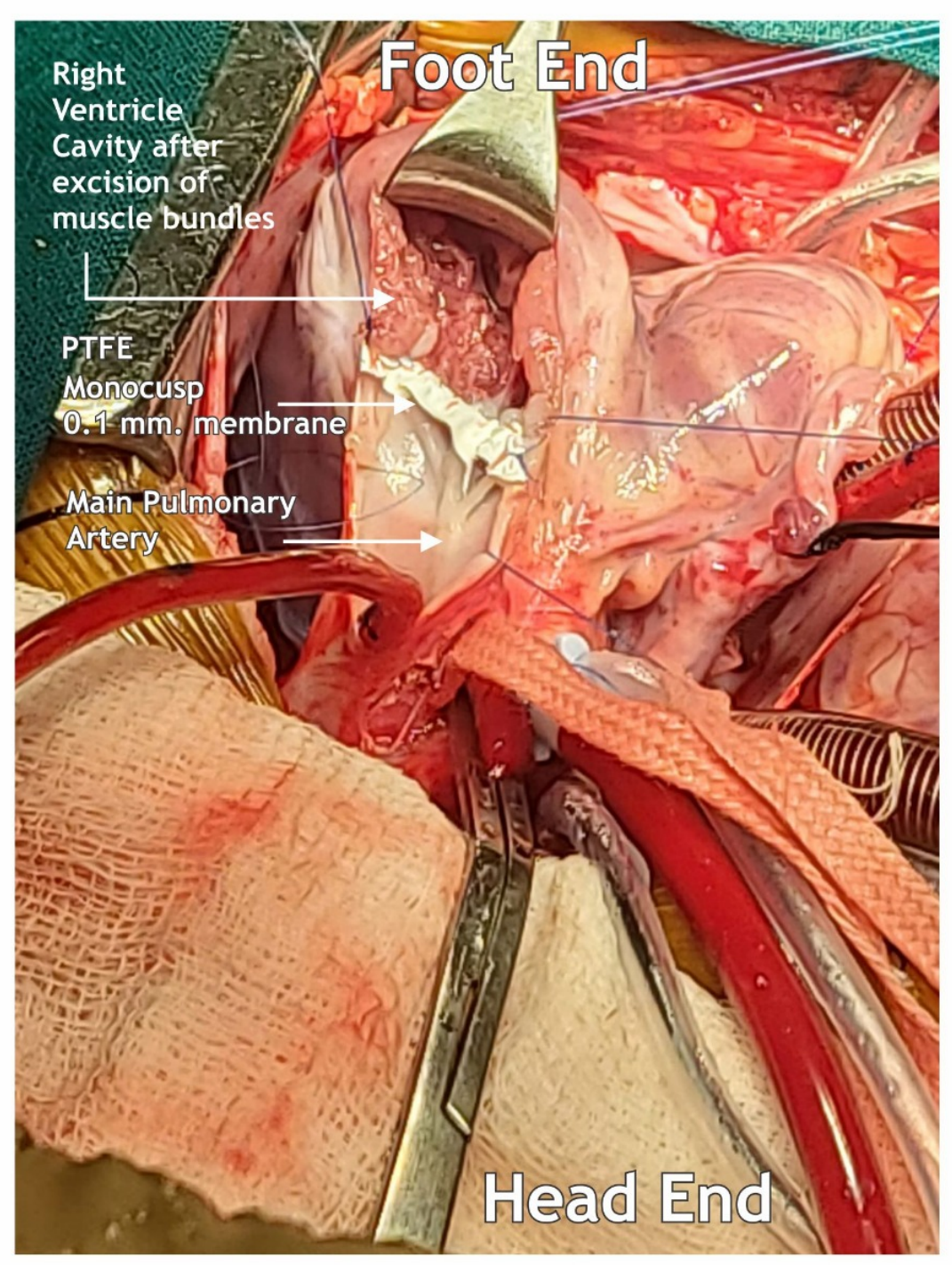




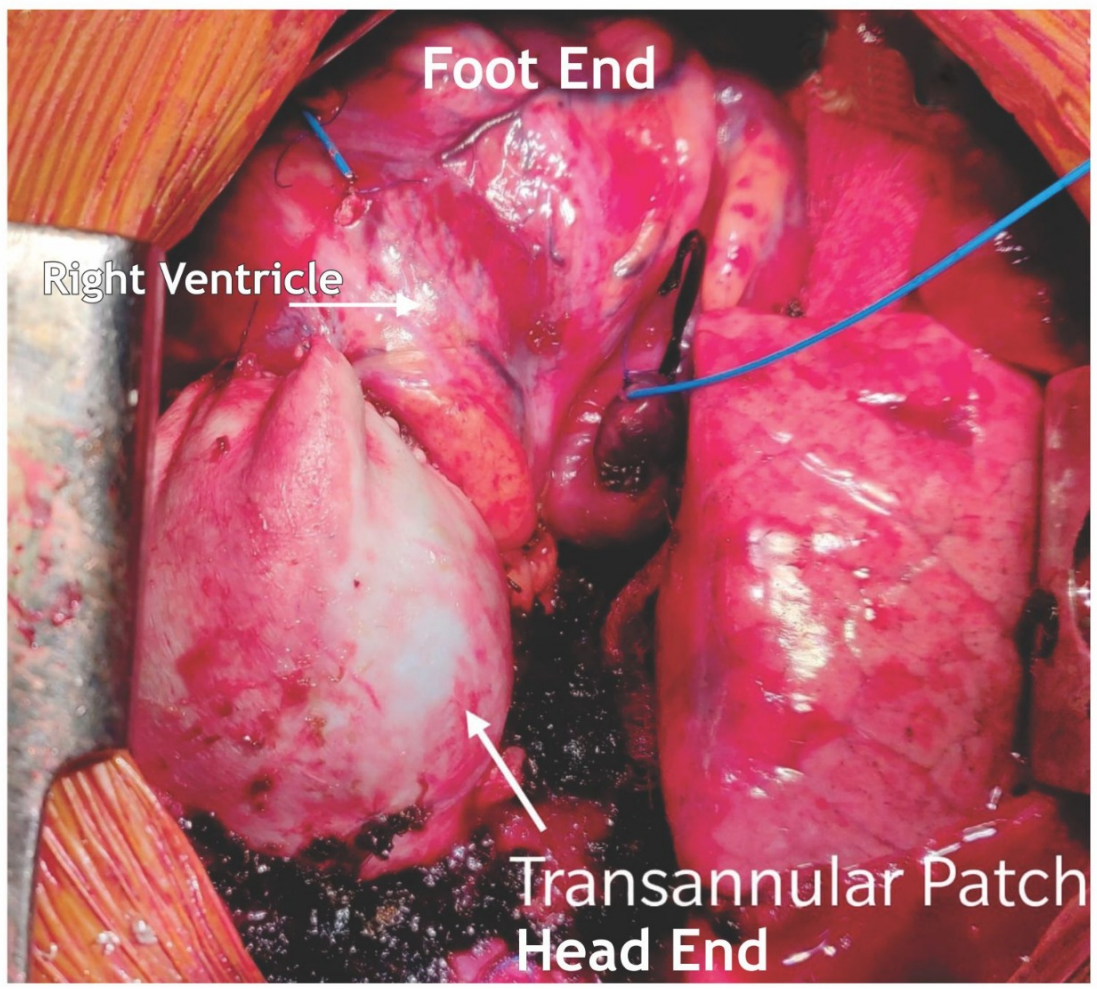




\section{PREPARATION OF MONOCUSP VALVE IN RIGHT VENTRICULAR OUTFLOW TRACT(RVOT)}

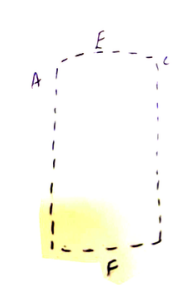

AUTOLOGOUS PERICARDIAL OUTFLOW PATCH
$\qquad G\}$

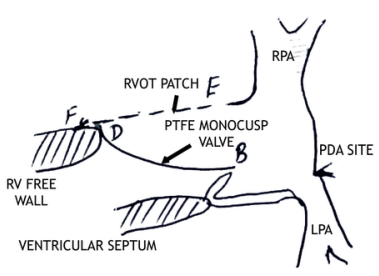

$\{\mathrm{F}\}$

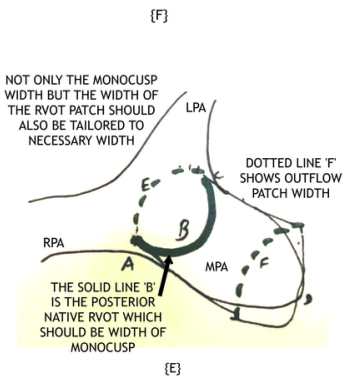

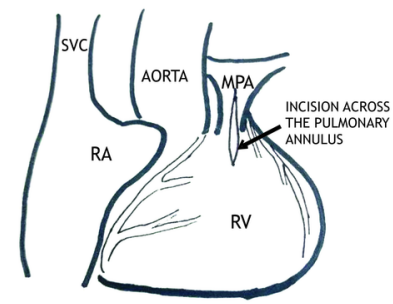

$\{A\}$
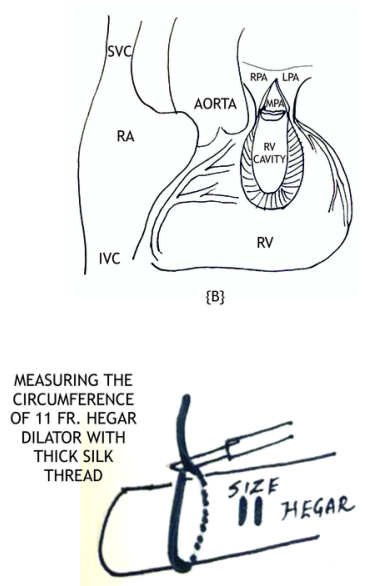

$\{C\}$

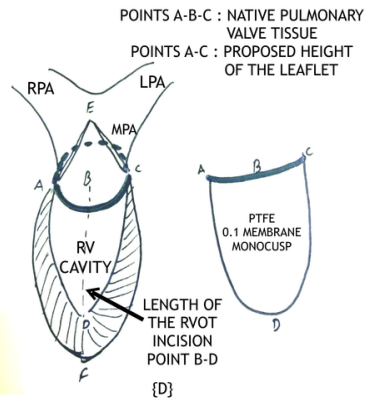

\section{Hosted file}

INDICES OF TOF EVALUATION(1).docx available at https://authorea.com/users/454413/articles/ 553920-higher-pulmonary-vein-index-from-preoperative-computed-angiography-good-surgicalresection-ensures-a-smooth-post-operative-recovery-sans-low-cardiac-output-syndrome-ina-tof-child-special-emphasis-on-indices-of-evaluation-monocusp-preparation 